\title{
TETRAPLOA ARISTATA BERKELEY \& BROOME (FUNGI, PLEOSPORALES), A NEW TAXON TO POLAND
}

\author{
MONIKA KARPIŃSKA-KOŁACZEK ${ }^{1}$, PIOTR KOŁACZEK ${ }^{1}$, \\ WALDEMAR HEISE ${ }^{2}$, GRZEGORZ WOROBIEC ${ }^{3}$ \\ ${ }^{1}$ Department of Palaeobotany, \\ Institute of Botany, Jagiellonian University \\ Lubicz 46, 31-512 Kraków, Poland \\ e-mail: monika_kk@interia.eu \\ 2 Department of Plant Ecology, \\ Institute of Botany, Jagiellonian University \\ Lubicz 46, 31-512 Kraków, Poland \\ ${ }^{3}$ Department of Palaeobotany, \\ Władysław Szafer Institute of Botany, Polish Academy of Sciences \\ Lubicz 46, 31-512 Kraków, Poland
}

(Received: January 11, 2010. Accepted: May 5, 2010)

\begin{abstract}
Tetraploa aristata Berkeley \& Broome represents the anamorphic stage of a pleomorphic fungus with holomorph Tetraplosphaeria tetraploa (Scheuer) Kaz. Tanaka \& K. Hiray (三Lophiostoma tetraploa (Scheuer) Aptroot \& K.D. Hyde). Until now this taxon has not been reported in Poland, where it is probably on the fringe of its distribution. Conidia of Tetraploa aristata were found during palynological analyses of modern surface samples and later on the decaying leaves of Phleum phleoides from xeric grasslands in Kraków and its vicinity. Since Tetraploa aristata was discovered during palynological analysis, this method might be considered to be a useful tool for investigations of contemporary microfungal mycobiota.
\end{abstract}

KEY WORDS: Tetraploa, Hyphomycetes, Pleosporales, Lophiostoma, Massarina, Tetraplosphaeria, modern pollen spectra.

\section{INTRODUCTION}

Tetraploa Berkeley \& Broome represents the anamorphic (asexual) stage of a pleomorphic fungus, a member of the dematiaceous staurospore hyphomycetes (Ellis 1971). A teleomorph of Tetraploa aristata was described by Scheuer (1991) as Massarina tetraploa Scheuer (Ascomycetes, Pleosporales). The holomorph of Tetraploa aristata and Massarina tetraploa was established by Hyde et al. (2002) as Lophiostoma tetraploa (Scheuer) Aptroot \& K.D. Hyde (see also Index Fungorum 2009). Recently Tanaka et al. (2009) created a new pleosporean family Tetraplospheriaceae Kaz. Tanaka and K. Hiray to integrate Tetraploa-like fungal anamorphs and created a new combination Tetraplosphaeria tetraploa (Scheuer) Kaz. Tanaka \& K. Hiray for holomorph Lophiostoma tetraploa.

Pleosporales are a scarcely recognized group in Poland; only 11 species of genus Lophiostoma Ces. \& De Not. and 6 of Massarina Sacc. have been reported (Mułenko et al.
2009). Until now 14 members of the genus Tetraploa have been described worldwide (Index Fungorum 2009).

This taxon has not been hitherto reported in Poland. In 2008 and 2009, during palynological analysis of modern surface samples collected from xeric grasslands in Kraków and its vicinity, Tetraploa aristata was discovered at several localities within this area. The purpose of this paper is to present the morphology of Polish specimens of the fungus, give ecological notes and some information about its distribution in Poland.

\section{Palaeobotanical data}

Fossil remains of the genus Tetraploa (also known as Frasnacritetrus Taugourdeau, see Worobiec et al. 2009) are definitely known from the Late Cretaceous and regularly reported from the Miocene from pollen spectra mainly outside Europe (Samant and Mohabey 2009; Worobiec et al. 2009). Identical to Tetraploa aristata are microfossils Type 89: Tetraploa aristata Berkeley \& Broome found in 
Holocene peat deposits in the Netherlands and Germany (Van Geel 1978). Tetraploa aristata was also found in Poland in the Upper Miocene deposits of Józefina (Worobiec et al. 2009) and in sediments of the Gołębiewo I site (a peat bog in the Gdańsk Uplands) and occurrence of its conidia was dated back to about 4200-3700 yrs cal. BP (Pędziszewska 2008).

According to Worobiec et al. (2009) the presence of Tetraploa aristata in fossil pollen spectra indicates a warm temperate climate. Sharma (1976), Saxena and Sarkar (1986) and Worobiec et al. (2009) found fossil conidia of Tetraploa associated with graminaceous pollen grains, sometimes in quantity (Worobiec et al. 2009). Taking into consideration that contemporary Tetraploa aristata is usually found on grasses and other monocotyledons, the incidence of fossil conidia of Tetraploa aristata implies a considerable share or even dominance of monocotyledons (especially grasses) in local vegetation and possibly the presence of open vegetation e.g. grasslands (comp. Peglar 1993).

\section{MATERIAL AND METHODS}

More than 10 subsamples as material for analysis were taken using a random pinch technique from an area ranging from 1 and $4 \mathrm{~m}^{2}$ in Piekary up to an area of $100 \mathrm{~m}^{2}$ within Kraków. The subsamples were usually parts of mosses, soil surface samples and detritus, which were homogenized together in plastic bags in order to obtain one amalgamated sample for palynological analyses (Adam and Mechringer 1975). A description of the surrounding vegetation was formulated according to the Braun-Blanquet (1965) method. The identification of plant communities was done using the Matuszkiewicz manual (2005).
For palynological analyses subsamples of $1 \mathrm{~cm}^{3}$ from every sample were acetolyzed using a modified Erdtman method (Faegri and Iversen 1989). One Lycopodium tablet of a known number of spores was added to every sample in order to evaluate the concentration of counted sporomorphs (Stocmarr 1971). After this preparation, slides for microscopic analyses were made and were then analyzed under a ZEISS AMPLIVAL microscope using 400× and 1000x magnification. The conidia of Tetraploa found in the slides were assigned to the species Tetraploa aristata on the basis of a paper by Van Geel (1978). This identification was checked later with experts who confirmed it (C. Scheuer and K.D. Hyde person. comm.).

In order to find this taxon in situ on its possible host, supplementary samples of the dead leaves of grasses were collected in July 2009 in previously chosen areas in Piekary. Macroscopic analyses were done using a Nikon SMZ 800 stereoscopic microscope under $63 \times$ magnification. The investigated leaf remains were then acetolyzed and the slides subsequently prepared were scanned under a microscope to finally confirm the presence of conidia of Tetraploa aristata.

\section{RESULTS}

\section{Taxonomy and morphology}

Anamorph: Tetraploa aristata Berk. \& Broome, Ann. Mag. nat. Hist., Ser. 2 5: 459 (1850).

Teleomorph: Massarina tetraploa Scheuer, Mycol. Res. 95(1): 126 (1991); Ascomycetes, Dothideomycetes, Pleosporales, Massarinaceae.

Holomorph: Tetraplosphaeria tetraploa (Scheuer) Kaz. Tanaka \& K. Hiray, in Tanaka et al., Stud. Mycol. 64: 182

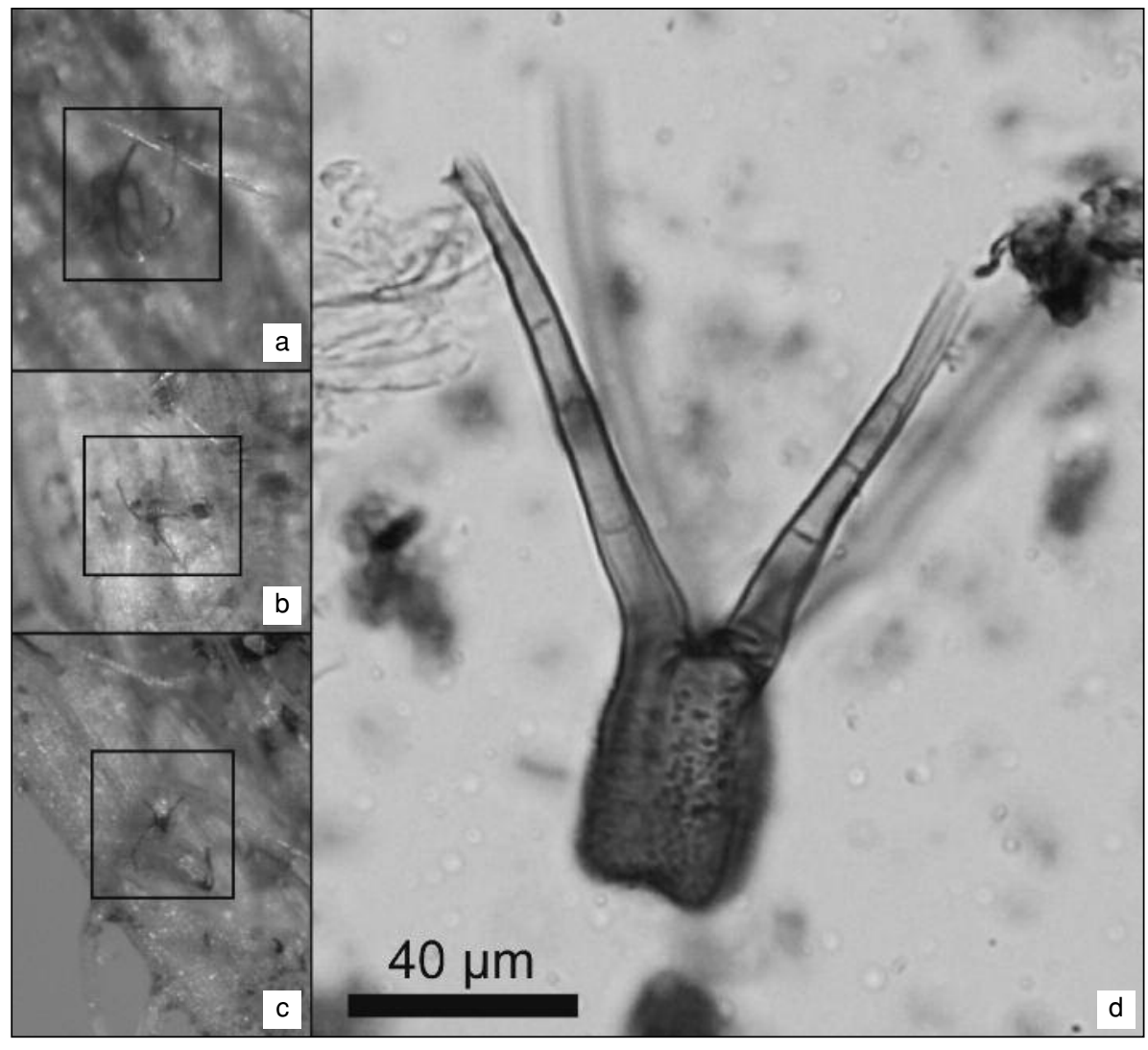

Fig. 1. Conidia of Tetraploa aristata: a-c on dead leaves of Phleum phleoides (63x magnification); $d$ - from modern surface sample (400× magnification). Photo: M. Karpińska-Kołaczek. 
TABLE 1. A description of vegetation at the localities with the occurrence of Tetraploa aristata with a number of conidia found in the surface soil sample and their estimated concentration.

\begin{tabular}{|c|c|c|c|c|}
\hline No. & Site & Association type; main species occur within analysed plot & $\begin{array}{c}\text { Number } \\
\text { of conidia found } \\
\text { in sample }\end{array}$ & $\begin{array}{c}\text { Estimated } \\
\text { concentration } \\
\text { of conidia } \\
\left(/ \mathrm{cm}^{3} \text { of }\right. \\
\text { surface sample })\end{array}$ \\
\hline 1 & Piekary I & Koelerio-Festucetum rupicolae; Phleum phleodides (20\%) and Stachys recta $(10 \%)$ & 33 & 2619 \\
\hline 2 & Piekary II & Geranium sanguineum aggregation; Geranium sanguineum (about 95\%) & 1 & 107 \\
\hline 3 & Mydlniki & $\begin{array}{l}\text { Koelerio-Festucetum rupicolae (initial phase); Festuca rupicola }(20 \%), \\
\text { Phleum phleoides }(10 \%), \text { Vicia grandiflora }(10 \%) \text { and Artemisia campestris }(10 \%)\end{array}$ & 10 & 2255 \\
\hline 4 & Krzemionki & $\begin{array}{l}\text { Koelerio-Festucetum rupicolae; Festuca rupicola (25\%), Thymus austriacus }(25 \%) \\
\text { and Brachypodium pinnatum }(10 \%)\end{array}$ & 16 & 2094 \\
\hline 5 & Wzgórze Benedykta & $\begin{array}{l}\text { Koelerio-Festucetum rupicolae (degenerated); Festuca rupicola }(40 \%) \text {, } \\
\text { Koeleria macrantha }(30 \%) \text { and Thymus sp. }(30 \%)\end{array}$ & 1 & 177 \\
\hline 7 & Bielany II & $\begin{array}{l}\text { Koelerio-Festucetum rupicolae; Festuca rupicola }(30 \%) \\
\text { and Arrhenatherum elatius }(20 \%)\end{array}$ & 4 & 719 \\
\hline 8 & Bielany III & $\begin{array}{l}\text { Koelerio-Festucetum rupicolae; Festuca rupicola }(30 \%), \text { Koeleria macrantha }(20 \%) \\
\text { and Phleum phleoides }(5 \%)\end{array}$ & 5 & 926 \\
\hline
\end{tabular}

(2009); Ascomycetes, Dothideomycetes, Pleosporales, Tetraplospheriaceae [ $\equiv$ Lophiostoma tetraploa (Scheuer) Aptroot \& K.D. Hyde, in Hyde, Wong \& Aptroot, Fungal Diversity Res. Ser. (Hong Kong) 7: 108 (2002); Ascomycetes, Dothideomycetes, Pleosporales, Lophiostomataceae].

In the investigated material the conidia of typical Tetraploa aristata are verrucose and consist of 4 columns of two or four cells (every column is 38-42 $\mu \mathrm{m}$ long and 16-19 $\mu \mathrm{m}$ width), which terminates in septate appendages, which are verrucose pigmented and up to $80 \mu \mathrm{m}$ long (Fig. 1).

This description was prepared on the basis of the selected well-preserved forms, due to the fact that most of the conidia found were severely damaged.

\section{Ecological notes}

Tetraploa aristata is usually found as a saprophyte on grasses and other monocotyledons (Ellis 1971) although it has rarely been recorded on dicotyledons (Citrus, Eucalyptus, Heracleum, Impatiens, Liquidambar, and Quercus) and occasionally also on Pinus (Farr et al. 2009). It is sometimes found on decaying wood and leaf litter (Vittal 1976; Révay 1993) as well. Some researchers (e.g. SchoenleinCrusius and Piccolo Grandi 2003) have reported Tetraploa aristata together with aquatic hyphomycetes. Tetraploa aristata is reported on rare occasions as a human pathogen (Markham et al. 1990).

Within the area of Poland the presence of Tetraploa aristata conidia was confirmed on the dead leaves of Phleum phleoides from the Piekary I site near Kraków (Table 1, Fig. 2). In this and other sites the taxon was detected in modern surface samples. Specimens of Phleum phleoides occurred within most of examined plots and in the vicinity of every of them. The highest concentration of conidia was found in modern surface samples collected from the Piekary I, Mydlniki and Krzemionki sites and exceeded a value of 2000 specimens $/ \mathrm{cm}^{3}$ (Table 1). What is more in these plots Phleum phleoides occurred more numerous than in the others. Taking into consideration a broad spectrum of monocotyledonous hosts of Tetraploa aristata, the presence of this taxon is also possible on dead leaves of other grass species which were detected in the analyzed plots e.g. Agrostis capillaris, Arrhenatherum elatius, Briza media, Dactylis glomerata, Elymus repens, Festuca rubra, F. rupicola, Koeleria macrantha and Poa pratensis.

\section{Distribution}

Tetraploa aristata is distributed mainly in subtropical and tropical regions (Ellis 1971; Farr et al. 2009). Until now neither $T$. aristata nor other species of Tetraploa have been reported in the contemporary mycobiota of Poland, and neither have Massarina tetraploa and Lophiostoma tetraploa (Mułenko et al. 2009). In other European countries conidia of Tetraploa aristata have been reported in Belgium (de Meulder 2002), Hungary (Révay 1993), Denmark, Germany, Italy, and United Kingdom (Farr et al. 2009), all countries with a mild climate. Tetraploa sp. (probably $T$. aristata) has been found in Spain (Diaz et al. 1998) and France (Proctor and Lambert 1961).

Conidia of the genus Tetraploa (mainly of Tetraploa aristata) are found as an accessory element among airborne fungal spores in warm regions of the world, e.g. Taiwan, Mexico, Spain, Australia, Canary Island, India, Martinique, USA, Italy (Tseng and Chen 1982; Calderón et al. 1997; Diaz et al. 1998; Mitakakis and Guest 2001; La-Serna et al. 2002; Jothish and Nayar 2004; Desbois et al. 2006; Codina 2008; Magyar et al. 2009). In Poland they have been observed in the course of aerobiological investigations only in Kraków (D. Myszkowska and D. Stępalska pers. comm.). Conidia of Tetraploa are sporadically transported by wind to such far-flung places as Antarctica (Marshall 1996).

Conidia of Tetraploa aristata were found in eight sites in Poland, six of which are located within the area of Kraków and two in Piekary (6 km to the south-west of Kraków) (Table 2, Fig. 2).

\section{CONCLUSIONS}

1. Tetraploa aristata is a new species for contemporary Polish microfungal mycobiota. 


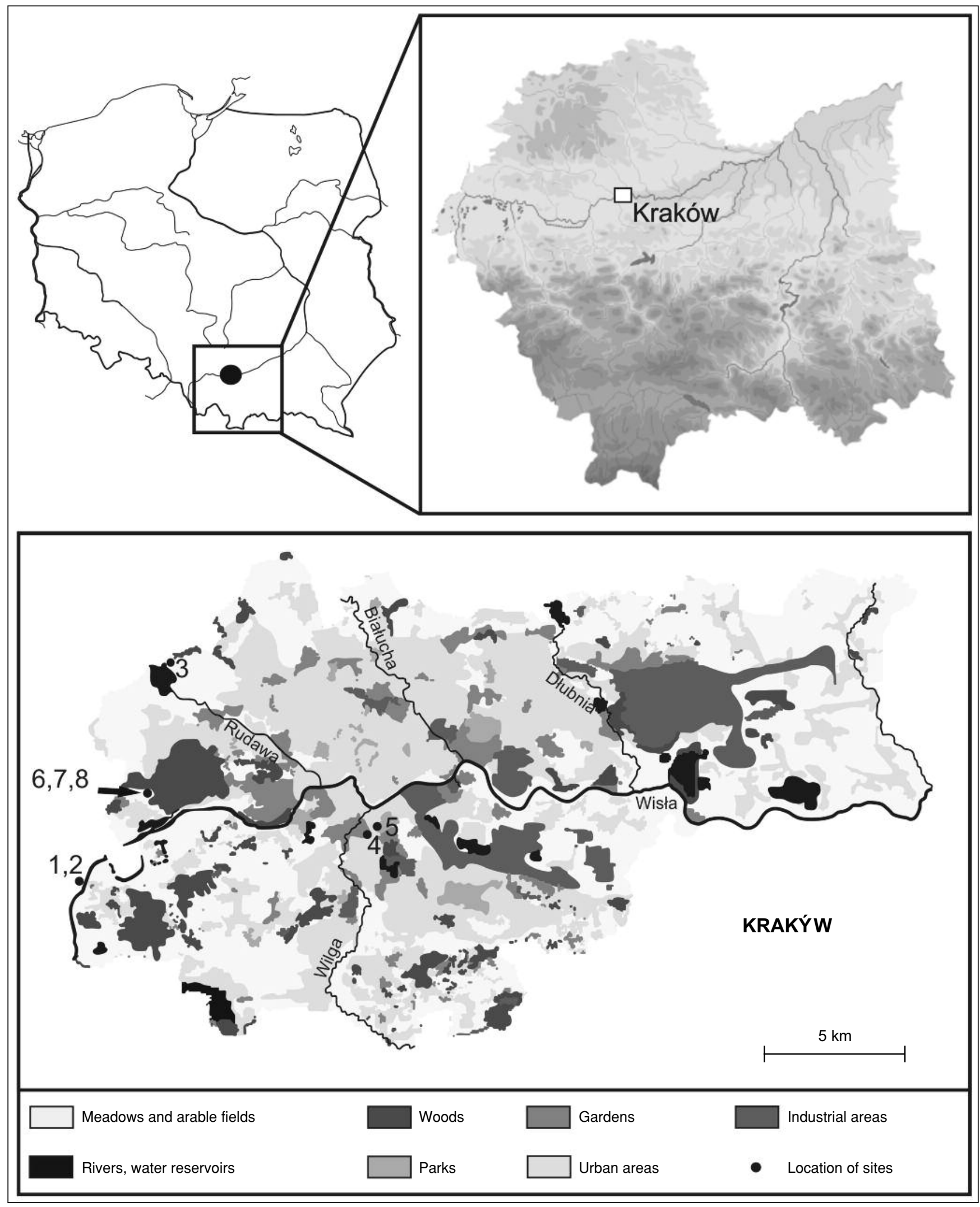

Fig. 2. Location in Poland and distribution of Tetraploa aristata in Kraków and its vicinity. Numbers of sites follows numbers in Table 1. Based on the map - Xerothermic grasslands in Kraków (2009).

2. This taxon occurs in Europe mainly in the Mediterranean area and Western Europe, and its closest sites are in Hungary and Germany. Polish sites of Tetraploa aristata located in Kraków and its vicinity are probably on the fringe of its distribution, hence its connection with xeric habitats with strong exposure to the sun and a warm microcli- mate. This microfungus usually grows on decaying leaves of grasses, and its occurrence in situ was confirmed on $\mathrm{Ph}$ leum phleoides specimens.

3. Palynological analysis of modern surface samples might be useful for analyses of microfungal mycobiota in different habitats and may contribute to the finding of new taxa. 
TABLE 2. Description of localities of Tetraploa aristata. The numbers follow Table 1 and Figure 2.

\begin{tabular}{|c|c|c|c|c|c|c|c|c|c|}
\hline No & Site & Site description & $\begin{array}{l}\text { Latitude } \\
\qquad\left({ }^{\circ} \mathrm{N}\right)\end{array}$ & $\begin{array}{l}\text { Longitude } \\
\left({ }^{\circ} \mathrm{E}\right)\end{array}$ & $\begin{array}{l}\text { Altitude } \\
\text { (m a.s.1.) }\end{array}$ & Exposure & $\begin{array}{l}\text { Incli- } \\
\text { nation }\end{array}$ & $\begin{array}{c}\text { Date } \\
\text { of sample } \\
\text { collection }\end{array}$ & Leg. \\
\hline 1 & Piekary I & Part of a rocky limestone slope & $50^{\circ} 05^{\prime} 40.6^{\prime \prime}$ & $19^{\circ} 47^{\prime} 39.1^{\prime \prime}$ & 207 & SW & $65.00 \%$ & 10.06 .2008 & $\begin{array}{c}\text { M. Karpińska- } \\
\text {-Kołaczek }\end{array}$ \\
\hline 2 & Piekary II & Part of a limestone hill & $50^{\circ} 05^{\prime} 40.7^{\prime}$, & $19^{\circ} 47^{\prime} 39.3^{\prime}$, & 207 & $\mathrm{~S}$ & $10.00 \%$ & 10.06 .2008 & $\begin{array}{c}\text { M. Karpińska- } \\
\text {-Kołaczek }\end{array}$ \\
\hline 3 & Mydlniki & $\begin{array}{l}\text { Part of the north-western slope } \\
\text { of Krzemionki hill within a limestone } \\
\text { quarry that was working until } \\
\text { the beginning of the 20th century }\end{array}$ & $50^{\circ} 05^{\prime} 15.6^{\prime \prime}$ & $19^{\circ} 50^{\prime} 38.3^{\prime \prime}$ & 230 & SEE & $10.00 \%$ & 07.05 .2009 & $\begin{array}{c}\text { M. Karpińska- } \\
\text {-Kołaczek }\end{array}$ \\
\hline 4 & Krzemionki & $\begin{array}{l}\text { Part of the north-western slope } \\
\text { of Krzemionki hill within a limestone } \\
\text { quarry that was working until } \\
\text { the beginning of the } 20 \text { th century. }\end{array}$ & $50^{\circ} 02^{\prime} 09.6^{\prime \prime}$ & $19^{\circ} 56^{\prime} 39.7^{\prime \prime}$ & 220 & NE & $40.00 \%$ & 28.04.2009 & $\begin{array}{c}\text { M. Karpińska- } \\
\text {-Kołaczek }\end{array}$ \\
\hline 5 & $\begin{array}{l}\text { Wzgórze } \\
\text { Benedykta }\end{array}$ & $\begin{array}{l}\text { An area on the western slope } \\
\text { of Krzemionki hill that } \\
\text { is being quarried for limestone } \\
\text { (The "Nad Matecznym" quarry) }\end{array}$ & $50^{\circ} 02^{\prime} 12.5^{\prime}$, & $19^{\circ} 56^{\prime} 45.0^{\prime \prime}$ & 215 & S & $40.00 \%$ & 03.06.2009 & $\begin{array}{c}\text { M. Karpińska- } \\
\text {-Kołaczek }\end{array}$ \\
\hline 6 & Bielany I & $\begin{array}{l}\text { Part of the southern slope of Srebrna } \\
\text { Góra located within the main part } \\
\text { of the Wolski Forest on an upper } \\
\text { section of the hill in a part } \\
\text { of the slope which is seasonally } \\
\text { exploited as arable land. }\end{array}$ & $50^{\circ} 02^{\prime} 41.2^{\prime}$, & $19^{\circ} 49^{\prime} 53.4^{\prime \prime}$ & 250 & SW & $10.00 \%$ & 14.06.2009 & $\begin{array}{c}\text { M. Karpińska- } \\
\text {-Kołaczek }\end{array}$ \\
\hline 7 & Bielany II & $\begin{array}{l}\text { Part of the southern slope of Srebrna } \\
\text { Góra located within the main part } \\
\text { of the Wolski Forest on the slope } \\
\text { of a gully that has been cut into } \\
\text { the hill from the south with numerous } \\
\text { outcrops of limestone }\end{array}$ & $50^{\circ} 02^{\prime} 41.7^{\prime \prime}$ & $19^{\circ} 49^{\prime} 53.6^{\prime \prime}$ & 254 & SW & $10.00 \%$ & 14.06.2009 & $\begin{array}{c}\text { M. Karpińska- } \\
\text {-Kołaczek }\end{array}$ \\
\hline 8 & Bielany III & $\begin{array}{l}\text { Part of the southern slope of Srebrna } \\
\text { Góra located within the main part } \\
\text { of the Wolski Forest on the top part } \\
\text { of the hill on the boundary between } \\
\text { seasonally exploited arable land } \\
\text { and a road }\end{array}$ & $50^{\circ} 02^{\prime} 42.1^{\prime \prime}$ & $19^{\circ} 49^{\prime} 53.5^{\prime \prime}$ & 251 & NW & $5.00 \%$ & 14.06.2009 & $\begin{array}{c}\text { M. Karpińska- } \\
\text {-Kołaczek }\end{array}$ \\
\hline
\end{tabular}

4. Palaeobotanical analysis combined with an analysis of modern pollen and spore influx might give an answer to the question as to whether Tetraploa aristata in Poland is a relic, an invasive taxon, or a southern (southwestern) element on the fringe of its distribution.

\section{ACKNOWLEDGMENTS}

The English translation of the manuscript was financially supported by the Association of Doctoral Students of the Jagiellonian University. We express our gratitude to Christian Scheuer and Kevin D. Hyde for help with taxon identification and the anonymous reviewer for his critical comments.

\section{LITERATURE CITED}

ADAM D.P., MEHRINGER P.J. 1975. Modern pollen surface samples - an analysis of subsamples. J. Res. U.S. Geol. Surv. 3:733-736.
BERKELEY M.J., BROOME C.E. 1850. Notices of British fungi (Nos. 380-437). Ann. Mag. Nat. Hist. Ser. 2(5), p. 459.

BRAUN-BLANQUET J. 1965. Plant Sociology: the Study of Plant Communities - Authorized English Translation of Pflanzensoziologie by J. Braun-Blanquet. Hafner Pub. Co, New York, pp. 1-439.

CALDERÓN C., LACEY J., MCCARTNEY A., ROSAS I. 1997. Influence of urban climate upon distribution of airborne Deuteromycete spore concentrations in Mexico City. Int. J. Biometeorol. 40:71-80.

CODINA R., FOX R.W., LOCKEY R.F., DEMARCO P., BAGG A. 2008. Typical levels of airborne fungal spores in houses without obvious moisture problems during a rainy season in Florida, USA. J. Investig. Allergol. Clin. Immunol. 18(3):156-162.

DE MEULDER H. 2002. Research on the occurrence of fungi on rushes (Juncus) - Part 4. AMK Mededelingen 4, pp. 97-102.

DESBOIS N., BEGUIN H., RUCK G., NERE J., NOLARD N. 2006. Calendrier des spores fongiques de la Martinique - Annual variation of fungal spores in atmosphere of Martinique. J. Mycol. Med. 16:189-196. 
DIAZ M.R., IGLESIAS I., JATO V. 1998. Seasonal variation of airborne fungal spore concentrations in a vineyard of NorthWest Spain. Aerobiologia 14:221-227.

ELLIS M.B. 1971. Dematiaceous Hyphomycetes. Commonwealth Mycological Institute, Kew, pp. 1-608.

FARR D.F., ROSSMAN A.Y., PALM M.E., MCCRAY E.B. 2009. Fungal Databases, Systematic Mycology and Microbiology Laboratory, ARS, USDA: http://nt.ars-grin.gov/fungaldatabases/.

FAEGRI K., IVERSEN J. 1989. Textbook of Pollen Analysis. Munksgaard, Copenhagen, pp. 1-328.

HYDE K.D., WONG W.S.W., APTROOT A. 2002. Marine and estuarine species of Lophiostoma and Massarina. In: Fungi in marine environments. K.D. Hyde. (ed.), Fungal Divers. Res. Ser. 7, pp. 93-109.

Index Fungorum 2009. An online database currently coordinated and supported by CABI Bioscience, CBS and Landcare Research. <http://www.speciesfungorum.org/>

JOTHISH P.S., NAYAR T.S. 2004. Airborne fungal spores in a sawmill environment in Palakkad district, Kerala, India. Aerobiologia 20:75-81.

LA-SERNA I., DOPAZO A., AIRA M.J. 2002. Airborne fungal spores in the Campus of Anchieta (La Laguna, Tenerife/Canary Is). Grana 41:119-123.

MAGYAR D., FRENGUELLI G., BRICCHI E., TEDESCHINI E., CSONTOS P., LI D., BOBVOS J. 2009. The biodiversity of air spora in an Italian vineyard. Aerobiologia 25:99-109.

MARKHAM W.D., KEY R.D., PADHYE A.A., AJELLO L. 1990. Phaeohyphomycotic cyst caused by Tetraploa aristata. J. Med. Vet. Mycol. 28:147-150.

MARSHALL W.A. 1996. Biological particles over Antarctica. Nature 383(6602):680.

MATUSZKIEWICZ W. 2005. Przewodnik do oznaczania zbiorowisk roślinnych Polski. Wydawnictwo Naukowe PWN, Warszawa, pp. 1-537. (in Polish)

MITAKAKIS T.Z., GUEST D.I. 2001. A fungal spore calendar for the atmosphere of Melbourne, Australia, for the year 1993. Aerobiologia 17:171-176.

MUŁENKO W., MAJEWSKI T., RUSZKIEWICZ-MICHALSKA M. 2009. A Preliminary Checklist of Micromycetes in Poland. Biodiversity of Poland Vol. 9, pp. 1-752.

PĘDZISZEWSKA A. 2008. Późnoholoceńska historia wybranych fitocenoz leśnych z udziałem grabu (Carpinus betulus L.) i buka (Fagus sylvatica L.) na pojezierzu Kaszubskim. PhD manuscript, Archive of the University of Gdańsk. Gdańsk, pp. 1-122. (in Polish)
PEGLAR S.M. 1993. Mid- and late-Holocene vegetation history of Quidenham Mere, Norfolk, UK interpreted using recurrent groups of taxa. Veget. Hist. Archaeobot. 2:15-28.

PROCTOR M.C.F., LAMBERT C.A. 1961. Pollen spectra from recent Helianthemum communities. New Phytol. 60(1):21-26.

RÉVAY A. 1993. Some new or interesting hyphomycetes from Hungary. Nova Hedwigia 56:473-482.

SAMANT B., MOHABEY D.M. 2009. Palynoflora from Deccan volcano-sedimentary sequence (Cretaceous-Palaeogene transition) of central India: implications for spatio-temporal correlation. J. Biosci. 34(5):811-23.

SAXENA R.K., SARKAR S. 1986. Morphological study of Frasnacritetrus Taugourdeau emend. from Tertiary sediments of Himachal Pradesh, India. Rev. Palaeobot. Palynol. 46(3-4): 209-225.

SCHEUER C. 1991. Massarina tetraploa sp. nov., the teleomorph of Tetraploa aristata. Mycol. Res. 95(1):126.

SCHOENLEIN-CRUSIUS I.H., PICCOLO GRANDI R.A. 2003. The diversity of aquatic Hyphomycetes in South America. Braz. J. Microbiol. 34(3):183-193.

SHARMA C. 1976. Some fungal spores from Quaternary deposits of Malvan, Gujajat. Palaeobotanist 23:79-81.

STOCKMARR J. 1971. Tablets with spores used in absolute pollen analysis. Pollen et Spores 13(4):615-621.

TANAKA K., HIRAYAMA K., YONEZAWA H., HATAKEYAMA S., HARADA Y., SANO T., SHIROUZU T., HOSOYA T. 2009. Molecular taxonomy of bambusicolous fungi: Tetraplosphaeriaceae, a new pleosporalean family with Tetraploa-like anamorphs. Stud. Mycol. 64(1):175-209.

TSENG HSI-YEN, CHEN ZUEI-CHING 1982. The interesting Air-Borne Fungus Spores. Taiwania 27:48-51.

VAN GEEL B. 1978. A palaeoecological study of Holocene peat bog sections in Germany and the Netherlands, based on the analysis of pollen, spores and macro- and microscopic remains of fungi, algae, cormophytes and animals. Rev. Palaeobot. Palynol. 25:1-120.

VITTAL B.P.R. 1976. Studies on litter fungi. I. Mycoflora of Atlantia and Gymnosporia litter. Proc. Indian Acad. Sci. 83B(4):133-138.

WOROBIEC E., WOROBIEC G., GEDL P. 2009. Occurrence of fossil bamboo pollen and a fungal conidium of Tetraploa $\mathrm{cf}$. aristata in Upper Miocene deposits of Józefina (Poland). Rev. Palaeobot. Palynol. 157:211-217.

Xerothermic grasslands in Kraków 2009. Map. Department of Ecosystem Studies, Institute of Environmental Sciences, Jagiellonian University. Viewed 31 October 2009, <http://www. eko.uj.edu.pl/przyrodakrakowa/mapy/mapa7_e.htm> 